\section{Double blind, placebo controlled study of metronidazole as a disease modifying agent in the treatment of rheumatoid arthritis}

\author{
D A S Marshall, J A Hunter, H A Capell
}

\begin{abstract}
Anecdotal reports suggest that metronidazole may have disease modifying activity in the treatment of rheumatoid arthritis. To assess possible beneficial effects a double blind, comparative trial of metronidazole and placebo was performed. Fifty patients with active rheumatoid arthritis were randomly allocated to receive active drug $(n=24)$ or placebo $(n=26)$ and reviewed at weeks $0,1,4$, $8,12,16$, and 24. Detailed assessment of drug safety, biochemical and haematological parameters, and efficacy was made at these dates. Dose regimen was $\mathbf{4 0 0} \mathbf{m g}$ twice daily from weeks 0 to eight, increasing to $400 \mathrm{mg}$ three times a day from weeks nine to 24 provided that no adverse effects were recorded.

Most patients were unable to tolerate metronidazole because of side effects or lack of efficacy, with only five (21\%) continuing to take the drug at 24 weeks. For those patients attaining 12 weeks of treatment an overall improvement in articular index and morning stiffness was found. No improvement in laboratory indices of disease activity was seen, however.

In this study metronidazole did not have disease modifying properties and was unacceptably toxic.
\end{abstract}

The nitroimidazole group of drugs includes some with known disease modifying activity in the treatment of rheumatoid arthritis. Levamisole and clotrimazole have both been shown to affect clinical and laboratory indices of disease activity, but toxicity has precluded their widespread use in practice. ${ }^{1}$ Occasional reports have suggested that metronidazole, another nitroimidazole with widespread clinical usage as an antibiotic and antiparasitic agent, might also be effective as a second line treatment for rheumatoid arthritis. ${ }^{2-4}$ This study therefore aimed, by means of a placebo controlled, double blind trial, at evaluating the effects of metronidazole on the clinical and laboratory indices of disease activity in rheumatoid arthritis.

\section{Patients and methods}

Fifty patients with clinical signs of active rheumatoid arthritis and pain or stiffness inadequately controlled by symptom relieving drugs alone were randomly allocated to receive treatment with either metronidazole $400 \mathrm{mg}$ twice daily or identical matching placebo tablets for an initial period of eight weeks, increasing to
$400 \mathrm{mg}$ three times a day for a further 16 weeks if tolerated. Randomisation was double blind and did not require any changes to concurrent drug treatment. Patients receiving treatment with systemic corticosteroids or who had received other disease modifying antirheumatic drugs within the preceding three months were excluded. Patients with hepatic or renal insufficiency were not included and nor were patients unable to undertake to abstain from all but very modest alcohol consumption. Table 1 gives details of the patient groups. Informed consent was obtained from all patients before entry into the study and permission for the study given by the local ethical committees.

Clinical assessments of duration of morning stiffness, articular index, ${ }^{5}$ grip strength, pain score (on visual analogue charts), and drug adverse effects were made at weeks $0,1,4,8$, 16, and 24. Laboratory tests (full blood count, urea, electrolytes, liver function tests, erythrocyte sedimentation rate, rheumatoid factor titre, were performed at the same time intervals. Because of reports of peripheral neuropathy as a result of metronidazole treatment, sensory function, as determined by light touch, vibration sense, and position sense, was tested at each clinical assessment. Withdrawal from treatment due to inadequate effect or adverse effects was recorded.

\section{STATISTICAL ANALYSIS}

Between-group comparisons were made with the Mann-Whitney $U$ test and within-group comparisons using Wilcoxon matched pairs. Because of the large number of patient withdrawals before completion of the study at 24 weeks, statistical analysis was performed only on the differences within or between groups from weeks 0 to 12 .

\section{Results}

Both groups of patients were well matched for disease duration, age, sex and disease activity (tables 1 and 3). At outset there was no significant difference in any parameter between

Table 1 Demographic details of patients. Mean value (range) is given

\begin{tabular}{lll}
\hline & $\begin{array}{l}\text { Metronidazole } \\
(n=24)\end{array}$ & $\begin{array}{l}\text { Placebo } \\
(n=26)\end{array}$ \\
\hline $\begin{array}{lll}\text { Age (years) } \\
\text { Disease duration (years) }\end{array}$ & $58(24-77)$ & $59(38-81)$ \\
Women/men & $9(1-36)$ & $\begin{array}{l}15(2-34) \\
20 / 6\end{array}$ \\
\hline
\end{tabular}
antinuclear factor titre, and $\mathrm{C}$ reactive protein)

(1)

\footnotetext{
Rheumatic Diseases, Glasgow Royal Infirmary, Glasgow G4 OSF,

Accepted for publication

15 October 1991

Centre for Rheumatic Diseases, Infirmary, Glasgow D A S Marshall Gartnavel General Hospital, Glasgow $\mathrm{J}$ A Hunter

1991
} 
the two groups (Mann-Whitney U test). As can be seen from the withdrawal graph (fig 1), only $5 / 24(21 \%)$ and $6 / 26(23 \%)$ continued to receive drug and placebo respectively until trial completion at week 24 . Table 2 gives details of

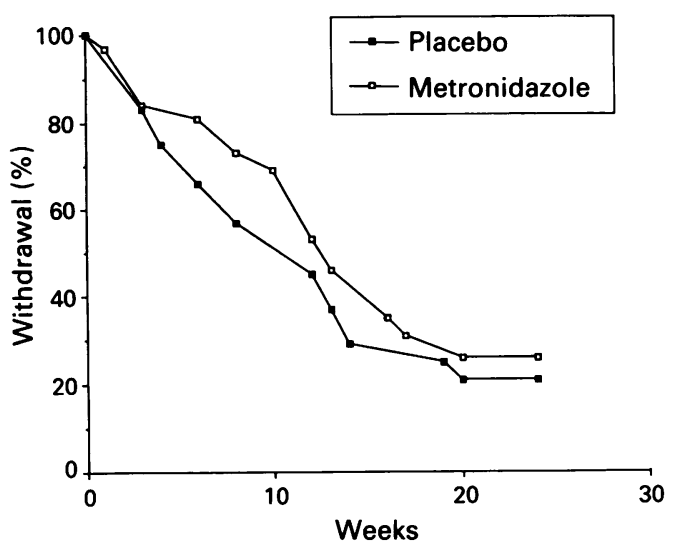

Figure 1 Patient withdrawals from study.

Table 2 Reasons for withdrawal

\begin{tabular}{lll}
\hline & $\begin{array}{l}\text { Metromidazole } \\
(n=24)\end{array}$ & $\begin{array}{l}\text { Placebo } \\
(n=26)\end{array}$ \\
\hline Lack of efficacy & 6 & 10 \\
Nausea & 7 & 2 \\
Rash & 1 & 3 \\
Peripheral neuropathy & 2 & 0 \\
Other & 3 & 5 \\
$\quad$ Defaulted & 1 & 3 \\
Dizziness & 1 & 1 \\
Altered taste sensation & 1 & 0 \\
Dyspnoea & 0 & 1 \\
Total withdrawals & $19(79 \%)$ & $20(77 \%)$ \\
\hline
\end{tabular}
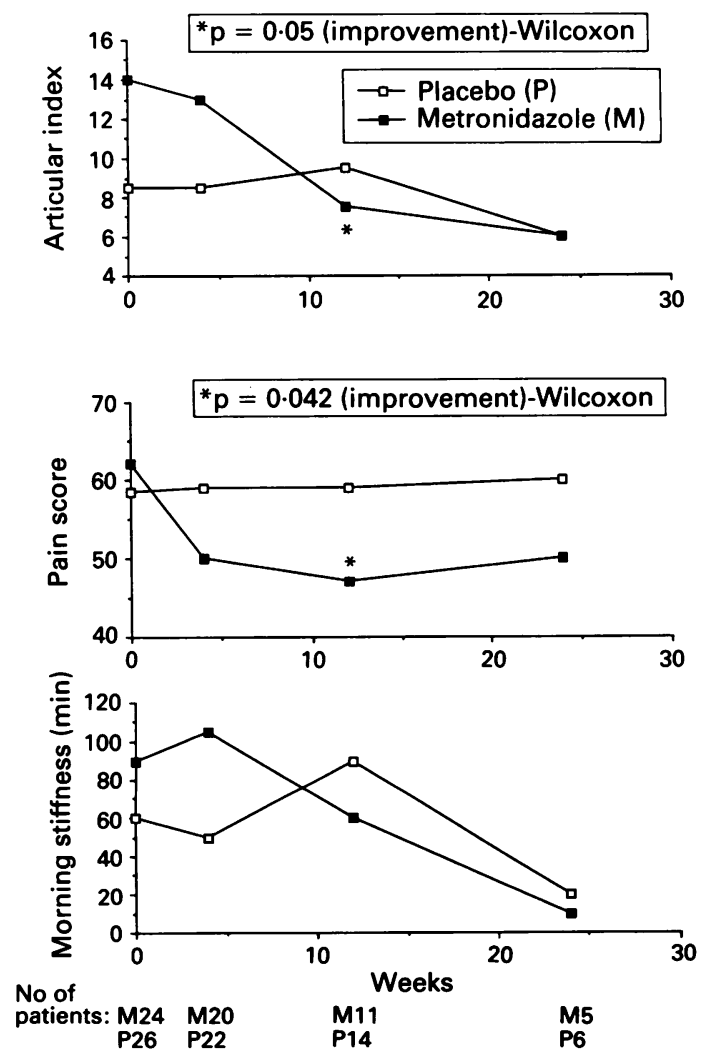

adverse drug reactions. The 'other' causes for withdrawal included headache, depression, sore throat, colitis, and dyspepsia.

Figure 2 shows the variation in clinical and laboratory parameters (expressed as median values) during the study. A significant improvement in articular index and pain score between weeks 0 and $12(\Delta 0-12)$ was seen in the group receiving metronidazole compared with those receiving placebo $(p=0.02$ and 0.025 respectively). Otherwise, no differences in $\Delta 0-12$ between drug and placebo were evident (table 3; Mann-Whitney U test). Within-group analysis (Wilcoxon matched pairs) showed significant improvement $\Delta 0-12$ in the articular index $(p=0.05)$ for patients receiving metronidazole and significant deterioration $\Delta 0-12$ in both $\mathrm{C}$ reactive protein $(p=0.045)$ and visual analogue pain score $(p=0.042)$ for those patients receiving placebo.

\section{Discussion}

This study illustrates the problems of placebo controlled studies of drugs in the treatment of rheumatoid arthritis as most patients withdraw owing to active disease (indeed, significant deterioration was found in some parameters in the placebo group). Thus, analysis of drug effects becomes increasingly difficult owing to the small number of patients remaining in the trial. Furthermore, the side effects of metronidazole were found to be intolerable in $12 / 24$ $(50 \%)$ patients. Most previous reports of metronidazole as a disease modifying agent in rheumatoid arthritis are anecdotal, but its use in

Figure 2 Clinical and laboratory variables (expressed as median values). 
Table 3 Comparison of drug and placebo at weeks 0 and 12. Results are given as median (ranges)

\begin{tabular}{|c|c|c|c|c|c|}
\hline & \multicolumn{2}{|c|}{ Metronidazole } & \multicolumn{2}{|l|}{ Placebo } & \multirow{2}{*}{$\begin{array}{l}\text { Mann-Whitney } \\
\Delta 0-12 \\
(p \text { value })\end{array}$} \\
\hline & Week 0 & Week 12 & Week 0 & Week 12 & \\
\hline Haemoglobin $(\mathrm{g} / \mathrm{l})$ & $\begin{array}{l}122 \\
(72-155)\end{array}$ & $\begin{array}{l}129 \\
(95-143)\end{array}$ & $\begin{array}{l}129 \\
(102-148)\end{array}$ & $\begin{array}{l}124 \\
(78-148)\end{array}$ & 0.01 \\
\hline Platelets $\left(\times 10^{9} / 1\right)$ & $\begin{array}{l}362 \\
(205-827)\end{array}$ & $\begin{array}{l}363 \\
(218-533)\end{array}$ & $\begin{array}{l}374 \\
(258-601)\end{array}$ & $\begin{array}{l}403 \\
(271-772)\end{array}$ & NS \\
\hline $\mathrm{ESR}^{*}(\mathrm{~mm} / \mathrm{h})$ & $\begin{array}{l}40 \\
(1-113)\end{array}$ & $\begin{array}{l}37 \\
(1-115)\end{array}$ & $\begin{array}{l}35 \\
(10-109)\end{array}$ & $\begin{array}{l}42 \\
(10-96)\end{array}$ & NS \\
\hline $\mathrm{CRP}^{*}(\mathrm{mg} / \mathrm{l})$ & $\begin{array}{l}21 \\
(10-135)\end{array}$ & $\begin{array}{l}16 \\
(10-69)\end{array}$ & $\begin{array}{l}24 \\
(10-140)\end{array}$ & $\begin{array}{l}38 \\
(10-98)\end{array}$ & NS \\
\hline $\mathrm{AI}^{*}$ & $\begin{array}{l}14 \\
(0-42)\end{array}$ & $\begin{array}{l}7 \cdot 5 \\
(0-21)\end{array}$ & $\begin{array}{l}8 \cdot 5 \\
(0-23)\end{array}$ & $\begin{array}{l}9 \cdot 5 \\
(0-24)\end{array}$ & 0.02 \\
\hline $\begin{array}{l}\text { Morning stiffness } \\
(\min )\end{array}$ & $\begin{array}{l}90 \\
(0-720)\end{array}$ & $\begin{array}{l}60 \\
(0-720)\end{array}$ & $\begin{array}{l}60 \\
(0-720)\end{array}$ & $\begin{array}{l}90 \\
(0-720)\end{array}$ & NS \\
\hline Grip: left & $\begin{array}{l}72 \\
(36-160)\end{array}$ & $\begin{array}{l}64 \\
(36-120)\end{array}$ & $\begin{array}{l}73 \\
(40-156)\end{array}$ & $\begin{array}{l}70 \\
(40-120)\end{array}$ & NS \\
\hline Grip: right $\dagger$ & $\begin{array}{l}80 \\
(40-116)\end{array}$ & $\begin{array}{l}84 \\
(44-134)\end{array}$ & $\begin{array}{l}74 \\
(38-120)\end{array}$ & $\begin{array}{l}78 \\
(42-105)\end{array}$ & NS \\
\hline Pain score & $\begin{array}{l}62 \\
(3-85)\end{array}$ & $\begin{array}{l}47 \\
(0-76)\end{array}$ & $\begin{array}{l}58 \cdot 5 \\
(18-90)\end{array}$ & $\begin{array}{l}59 \\
(30-100)\end{array}$ & 0.025 \\
\hline
\end{tabular}

${ }^{*} \mathrm{ESR}=$ erythrocyte sedimentation rate; $\mathrm{CRP}=\mathrm{C}$ reactive protein; $\mathrm{AI}=$ articular index. $+100 \mathrm{~mm}$ visual analogue chart. there is, however, no known correct dose of metronidazole in the treatment of rheumatoid arthritis. Despite their high dose, side effects were not reported as severe, and good subjective clinical results were obtained with improvement in up to $93 \%$ of patients. No objective clinical or laboratory data have been published to substantiate these findings. A clinical observation from these studies is of a Herxheimer reaction occurring in up to $85 \%$ of patients and being associated with a good clinical response to the drug. None of our patients manifested symptoms suggesting a Herxheimer reaction.

The only previously published placebo controlled study of metronidazole in rheumatoid arthritis was of 20 patients followed up for six weeks, and this found no differences in clinical or laboratory indices of disease activity. Our study followed up patients for a longer period and failed to identify a useful role for metronidazole in rheumatoid arthritis.

We thank Sister A Thompson for metrological assessment, Mrs D McKnight for statistical analysis, and May and Bake Pharmaceuticals for providing metronidazole and placebo.

(n) bacterial infections, inflammatory bowel disease is well documented. The side effect profile of the drug is also well reported. In this study nausea and vomiting affected $7 / 24(29 \%)$ with peripheral neuropathy occurring in $2 / 24(8 \%)$ patients, though this reversed on stopping the drug. A study of patients with Crohn's disease receiving metronidazole suggested peripheral neuropathy occurred in 11 of 13 , though only six of the 11 were symptomatic. ${ }^{6}$ Peripheral neuropathy has also been reported in amoebiasis treated with high dose metronidazole. ${ }^{7}$

Our dose of $400 \mathrm{mg}$ twice daily increasing to three times a day is less than that used by some authors, who advocate $2 \mathrm{~g}$ at night for two successive nights each week for six weeks ${ }^{4}$;
1 El-Ghobarey A F, Maurikakis M E, McLeod M, et al. Clinical and laboratory studies of levamisole in patients with rheumatoid arthritis. Q F Med 1978; 187: 385-400.

2 Harkness J A L, Griffin A J, Heinrich I, Gibson T, Grahame $R$. A double-blind comparative study of metronidazole and placebo in rheumatoid arthritis. Rheumatol Rehabil 1982; placebo in $\mathrm{rh}$

3 Pybus $\mathrm{P} \mathrm{K}$. Metronidazole in rheumatoid arthritis. $S$ Afr Med J 1984; 65: 454-6.

F 1984; 65: $454-6$.
Pybus P K. Metronidazole in rheumatoid arthritis. $S$ Afr Med $\underset{f}{1985}$; 67: $1039-40$.

5 Ritchie D M, Boyle J A, McInnes J M, et al. Clinical studies with an articular index for the assessment of joint tenderness in patients with rheumatoid arthritis. $Q \mathcal{F} \mathrm{Med} 1968 ; 37$ : 393-406.

6 Duffy L F, Daum F, Fisher S E, et al. Peripheral neuropathy in Crohn's patients treated with metronidazole. Gastroenterology $1985 ; 88$ : $681-4$.

7 World Health Organisation. Amoebiasis and its control. Bull World Health Organ 1985; 63: 417-26. 